This is an electronic reprint of the original article. This reprint may differ from the original in pagination and typographic detail.

Author(s): Mättö, Toni; Järvenpää, Marko; Rautiainen, Antti; Sippola, Kari

Title: Quality management in the public sector accounting department - (un)avoidable quality costs and unlikely financial impacts

Year: $\quad 2017$

Version:

Please cite the original version:

Mättö, T., Järvenpää, M., Rautiainen, A., \& Sippola, K. (2017). Quality management in the public sector accounting department - (un)avoidable quality costs and unlikely financial impacts. International Journal of Accounting and Finance, 7(3), 234-252. https://doi.org/10.1504/IJAF.2017.088029

All material supplied via JYX is protected by copyright and other intellectual property rights, and duplication or sale of all or part of any of the repository collections is not permitted, except that material may be duplicated by you for your research use or educational purposes in electronic or print form. You must obtain permission for any other use. Electronic or print copies may not be offered, whether for sale or otherwise to anyone who is not an authorised user. 


\title{
Quality management in the public sector accounting department - (un)avoidable quality costs and unlikely financial impacts
}

\author{
Toni Mättö*, Marko Järvenpää, Antti Rautiainen and Kari Sippola \\ Jyväskylä University \\ School of Business and Economics \\ P.O Box 35, 40014, Finland \\ Email: toni.m.matto@jyu.fi \\ *Corresponding author
}

\begin{abstract}
This paper investigates the nature of quality costs and the likelihood of their having financial impacts in the public sector. An illustrative quality development case project in an accounting department of a Finnish city administration is presented. The empirical data includes answers to a qualitative project question sheet, workshop material, and participative observation. Quality problems are classified according to their quality cost category and the extent to which they are avoidable. Some of the quality costs proved unavoidable and some are likely to lack financial impact, exhibiting sticky cost behaviour. The study indicates that certain prevention and appraisal costs in the public sector might not deliver the desired outcomes because of such sticky behaviour of costs. Traditional quality thinking holds that increased prevention and appraisal investments decrease failure costs. However, the extent to which these costs are avoidable has not been analysed in previous studies.
\end{abstract}

\section{Keywords}

Case study, Action research, Quality, Public sector, Cost classification, Cost stickiness

\section{Biographical notes}

Toni Mättö is a postdoctoral researcher in accounting at the Jyväskylä University School of Business and Economics. His research areas include public sector organizations, cost management, decision-making relevance and performance measurement. 
Marko Järvenpää is a professor in accounting at the Jyväskylä University School of Business and Economics. His research areas include management accounting change, strategic management accounting, roles of management accountants, sustainability accounting, performance measurement and cost management.

Antti Rautiainen is currently a professor in accounting at the Jyväskylä University School of Business and Economics, Finland. He is also a docent at the Tampere University Faculty of Management. His research areas include case research, performance measurement, risk, accountability, management accounting, financial statement analysis and public sector accounting.

Kari Sippola is a postdoctoral researcher in accounting at the Jyväskylä University School of Business and Economics. His areas of interest include management accounting, public sector organizations, quality and costing systems, process development, and constructive research approach.

\section{Acknowledgements}

We gratefully acknowledge the helpful and essential comments from the two anonymous reviewers. We also thank Pekka Pirinen for his support during the early stages of the research project. We appreciate the helpful comments received at the Annual Congress of the European Accounting Association 2012 Ljubljana. Finally we wish to thank the Jyväskylä Merchants Guild Foundation for funding the empirical part of the project. 


\section{Introduction}

Public sector organisations have been facing diminishing budgets and increasing demands for efficiency in recent years (Lapsley, 2008, 2009). According to Pollitt (2010), most countries now face the prospect of an extended period of public fiscal austerity, yet at the same time the demands for improved public services continues. This creates an imbalance between income, expenditure and expected quality of service.

However, Kuipers et al. (2014) note that there is a fundamental difference between private and public organisations in the political context of democracy and the juridical context with related legislation, rules and bureaucracy. Public organisations are affected by political influences to a greater extent than private companies, are restricted by rules concerning transactions between the public organisation and its environment, and structured in a more complex and bureaucratic way. In addition, public sector organisations strive for different, sometimes conflicting goals such as quality, efficiency, equality, legitimacy, reliability and due process (e.g. Kuipers et al., 2014). Moreover, clarity of goals is sometimes lost in the context of the many connected stakeholders in the public sector (Kuipers et al., 2014).

In an effort to increase efficiency in public sector administration, new public management (NPM) was introduced into the public sector management sphere from the 1980s (Hood, 1995). One important feature of NPM is the adoption of private sector management styles and techniques in the public sector context (Lapsley, 1999; Hood, 1995).

These developments also accentuate the need to analyse issues of quality management, quality $\operatorname{costs}^{1}$ and administrative practices in the public sector; for example, Krishnan (2006) suggests improving efficiency in public organisations by reducing quality related mistakes. Krishnan's review suggests that failure costs are generally higher in public organisations than in private sector ones. Indeed, Seokjin and Nakhai (2008) estimated that failure costs account for about half of the reported costs of quality (COQ) in manufacturing. In the public sector, however, quality cost management is complicated by legislative or contractual arrangements that are relatively fixed. This inflexibility, caused in part by legislative demands for service and the continuity of other previous commitments in the public sector, tends to mean that costs fall into fixed or indirect cost categories. We suggest that the likelihood of different quality costs being designated as

\footnotetext{
${ }^{1}$ Quality costs can be categorised as prevention, appraisal, and failure costs (PAF, see Feigenbaum, 1991). Prevention costs are associated with improvement projects and actions to prevent failure costs. Appraisal costs are costs arising from the inspection of services and products. Failure costs are the costs of either quality issues in the organisation (internal failures) or faulty services or products reaching the customer (external failures) (Feigenbaum, 1991; Juran, 1999).
} 
expenses or perceived to be avoidable or unavoidable in a public sector organisation depends on the circumstances (such as available capacity) and the communication of development needs (Barber et al., 2000; Donnelly, 1999; Järvinen, 2004; Pärl, 2014.)

Traditionally, cost accounting literature identifies variable and fixed costs. In the short term, variable costs are typically avoidable whereas fixed costs are unavoidable. Further, the term direct cost has been used to indicate costs associated with a particular action, product, or department, whereas indirect costs are associated with several products or departments, and often calculated as overhead costs (Horngren et al., 2012). However, the way in which these cost categories are used when analyzing public sector quality costs is not clear. This study investigates the nature of public sector quality costs by analysing the potential financial impact of the quality cost categories revealed in a case study.

Quality costs are neither necessarily avoidable nor do they necessarily affect expenses disclosed in the financial statements. For example, two people doing overlapping work may be considered a waste of resources and a failure cost, but in a case of excess capacity no more output can be generated and (in the short term at least) the same salary cost will be accrued regardless of the work the two people do. The regulation of dismissals further complicates downsizing, especially in the public sector. In addition, cost calculations can differ substantially between projects even in similar circumstances because of subjective cost accounting practices (Emsley, 2008). Subjectivity may also arise from unclear dialogue or one-way communication between different levels of the organisation (Pärl, 2014). Communicating the various responsibilities understandably may prevent problems associated with this kind of subjectivity, such as unclear job descriptions. Also, identifying a problem with no immediately discernible (stated or visible) financial impact, such as an overlapping work process, creates an opportunity to improve work processes and information sharing between organisational levels irrespective of the financial impact.

Activity based costing ( $\mathrm{ABC}$ ) literature has long identified the difference between capacity and resource use (Cooper and Kaplan, 1992; Kaplan and Cooper, 1997). However, quality theory has paid relatively little attention to this issue (see e.g., American Society for Quality, 2014). In the long run, extra capacity can be reduced, thus achieving savings from headcount reduction for example. However, in the Finnish public sector, firing staff is often difficult. Some staff are protected against dismissal based on their contracts or regulatory demands for some public services. Quality theory literature might thus benefit from analyses that differentiate capacity issues, such as the concepts of resources used and resources supplied (see also Kaplan and Cooper, 1997). 
Cost stickiness is a concept useful for analysing the behaviour of costs with relation to the organisation's economic activity. According to Balakrishnan et al. (2004), 'costs are classified as sticky if the magnitude of their increase associated with an increase in a firm's economic activity, is greater than the magnitude of their decrease associated with an equivalent decrease in a firm's economic activity'. Banker and Byzalov (2014) attribute cost stickiness to deliberate resource commitment decisions made by managers to maintain idle resources after volume declines, for example. They further suggest that sticky cost behaviour dictates that the traditional model of fixed and variable costs should be amended with a more nuanced analysis and expanded categorisation of different costs. Further, Dwivedi and Chakraborty (2015) investigated the non-profit sector and found that traditional costing systems were often incapable of providing accurate and useful information. The issue of quality costs in accounting offers a fruitful area to analyse the cost stickiness of the different quality costs and the likelihood of their being avoidable. Therefore, we ask: To what extent are the different quality costs in a public sector organisation's financial department avoidable and presented in the financial statements?

This paper offers an illustration of a quality project in a public sector accounting organisation. The quality costs of different initiatives and problems of the case project are analysed and classified according to their quality cost class (prevention, appraisal, and failure) and the extent to which they are avoidable (also referred to as their avoidability). The link between avoidability and the financial impact on the organisation is also considered. The remainder of the paper is organised as follows. The study first offers an overview of the discussion around quality in the public sector context, and then presents its methodology. The paper then describes the case study conducted in a Finnish municipality, presents the main findings, and discusses the insights arising from them.

\section{Quality in a public sector accounting context}

Public sector quality management research has focused on several issues, such as quality costs (Barber et al., 2000), quality models (Redman et al., 1995), and the link between the NPM and quality (see e.g., English and Guthrie, 2003; Erridge et al., 1998; Lapsley, 2008, 2009). NPM reforms advocate applying private sector techniques, such as quality management, in the public sector (see Sedevich-Fons, 2012). However, when selecting a quality benchmark from the private sector, circumstances and operational characteristics specific to the public sector must be considered. The development of processes in accounting organisations is typically linked with accounting information system change and the revision of an organisational structure (Hyvönen et al., 2012; Järvenpää, 2007; Järvenpää et al., 2008; Kearney, 2000; Malcolm, 1999). However, there is little research on developing quality within a public sector accounting department. As Hurmelinna- 
Laukkanen and Heiman (2012) point out there is also a need for empirical case analysis illustrating how organisations choose the right problems to solve.

Quality management research has typically connected with accounting by investigating quality costing methods (Freeman, 2008; Harrington, 1999; Hewins, 1993; Laszlo, 1997; Sedevich-Fons, 2012; Stolber, 1991), barriers to quality developments (Payne, 1992), the language of quality costing (Roden and Dale, 2000), or the economic effects of quality management (Payne, 1992; Sedevich-Fons, 2011). However, very little has been written about the quality costs of accounting functions, whether these costs are avoidable, or the development of quality in public sector accounting organisations. The public sector accounting organisation operates in a different environment from its private sector counterpart; it is governed by a municipal authority and there are political agendas involved.

Globalisation and the easing of market boundaries have led to extensive competition, societal changes, and restrained resources in the public sector. Järvinen (2004) notes that, with the exception of the healthcare arena, quality cost accounting has scarcely been used in the public sector. The financial services function in the public sector has received very little attention in the quality improvement literature. In addition, the extent to which the different PAF categories are avoidable has not been analysed in previous literature.

The American Society for Quality (ASQ, 2014) defines the COQ as 'the cost of not creating a quality product or service'. Thus, 1) every time work is redone, the $C O Q$ increases. Examples include reworking a manufactured item, retesting an assembly, rebuilding a tool, correcting a bank statement, or replacing a dish in a restaurant. It follows that 2) any cost that would not have been accrued if quality were perfect contributes to the COQ (ASQ, 2014). We argue that the first part of this definition includes costs that are sometimes inclusive of already paid hours or are part of inevitable quality costs, particularly in a public sector organisation. Examples of unavoidable failure costs would include those associated with strict employment contracts and the need to maintain some excess operating capacity. Thus, the second part of the definition would lead to the dismissal of some quality costs in the public sector as being related to actual costs since delivering perfect quality is in some instances attributable to cost stickiness (i.e. increasing quality does not necessarily reduce actual costs). However, the quality of the working process might still be increased and on occasion lead to higher or better output.

Total quality costs are the total of the costs incurred by investing in the prevention of defects and nonconformity, appraising a product or service for conformance to company quality levels, and failing to meet the requirements of internal and external customers 
(Feigenbaum, 1991). Schiffauerova and Thomson (2006) argue that since traditional cost accounting attributes costs by the categories of expenses instead of activities, COQ data must often be gathered through other methods. Foster (1996) states that data on quality problems can be obtained by a variety of means like expert review, simulation, questionnaires, or the case research method. Tsai (1998) used a company level database to supply various cost information elements for estimating COQ and tracking in a project merging $\mathrm{ABC}$ and $\mathrm{COQ}$ models. Robison (1997) emphasised a team-based data collection approach to identify process problems and the related quality costs.

Accounting functions are relatively unproblematic in terms of assessing financial costs because the main cost category is typically salaries: a mostly fixed and unavoidable cost. However, in terms of quality costs the situation is more ambiguous. This is because traditional quality costing does not differentiate between avoidable and unavoidable quality costs. Public sector units - in the wake of the rise of NPM methods - have implemented a raft of efficiency improvement initiatives but the distinction between avoidable and unavoidable costs has not been analysed in detail.

\section{Methodology and the research process}

The public sector accounting organisation (department) depicted in the empirical part of this study has elements of a shared service centre (SSC) (see, Hyvönen et al., 2012), and the accounting function has been separated from the rest of the municipal organisation. The accounting department handles bookkeeping, invoicing, payments, and prepares reports and financial statements for several public organisations within the municipality. Our case organisation employs eight people, thus being smaller than a typical SSC.

The empirical part of this paper illustrates the nature of quality costs and portrays quality cost development in a public sector accounting organisation. The case organisation pursued development through the Collaborative Approach for Managing Project cost of poor quality tool (CAMP, Malmi et al., 2004). The CAMP approach is based on interventionist action research in that it addresses problem solving through employee participation and co-operation between researchers and practitioners (see Coughlan and Coghlan, 2002; Jönsson and Lukka, 2005; Lewin, 1946).

The action research (AR) concept was established by Kurt Lewin (1946) and its different variants are widely used in the social sciences (see Coughlan and Coghlan, 2002; Jönsson and Lukka, 2005). This study analyses the implementation of the CAMP tool in a public sector case organisation. 
Figure 1 illustrates the CAMP stages proposed by Malmi et al. (2004). The CAMP research process has a number of fixed characteristics, such as workshops, tasks attributed to different workshops, identification of quality costs in terms of the PAF model, a procedure to identify quality failures, and an improvement ideas procedure. In addition, the method typically consists of a preliminary project question sheet that helps gather information about various problems in organisational processes. Other work phases such as analysing and prioritising the data are conducted between data generation phases.

\section{INSERT FIGURE 1 HERE}

Malmi et al. (2004) point out some possible limitations of the CAMP method; it is based on the assumption that an organisation's employees possess knowledge about the problems inherent in work processes. However, for example in complex public organisations with multiple interactions between individuals this might not always be the case. Further, this method identifies problems that are linked to the work process of the employees. Problems pertaining to organisational outcomes, like loss of goodwill or lost sales might not be found. Thus, this limitation is more likely to have an influence if the method is used in the private sector. Malmi et al. (2004) also note the potential sensitivity of the CAMP method to cross-functional representation of the employees in workshops, that is, if employees from a certain function, for example billing, are not able to attend the workshops or answer the preliminary question sheet, problems associated with billing will not be identified. This problem might be more pressing in large companies or organisations where finding time for such cross-functional representation can be challenging. In our case, all of the employees of the department attended the workshops and answered the preliminary question sheet.

The data informing this study were gathered through triangulation of sources, as is typical for a qualitative case study (Eisenhardt and Graebner 2007, Jönsson and Lukka 2005, Malmi and Granlund 2009). We used a preliminary question sheet to gather qualitative data, as well as workshop materials and observations made during the workshops. The chosen methodology helps to counter the threats to validity by using multiple sources (McKinnon 1988, Malmi and Granlund 2009). Moreover, the nature of the CAMP model is such that research findings are fed back to the members of the organisation for validation several times. This is done after each workshop phase has ended to ensure possible changes to the acquired data can be introduced at the start of the next workshop. As Otley (1980) notes, close contact with an organisation and feedback of the findings to research subjects serves to enhance the validity of findings. 
Research reliability deals with the possibility of obtaining similar results through repetition of the research. Although every case is unique in terms of the problems raised and initiatives created during the improvement project, we expect that the detailed description provided in this paper will make it possible to replicate the method itself in other similar contexts, thus making at least the method potentially generalizable.

\section{Case description}

The Finnish public sector context involves the state and about 300 municipalities taking care of the local government, education, social services and health care. Both state level taxes and municipality taxes are levied. Under austerity pressures municipalities have tried to combine their operations with other municipalities and created for example accounting service centers (Hyvönen et al., 2012). The empirical case study started in 2006 with contact with the manager of the accounting department of a Finnish municipality. At the time, the accounting department had eight full-time employees, including the manager. The proposed improvement project made relatively light demands on the staff's time, requiring them to complete a preliminary question sheet (Appendix) and commit two full days to participate in the workshops. The manager was aware of various issues in the department ranging from unclear responsibilities to typical bookkeeping errors and therefore supported seeking process improvements. The project was estimated to take a little over a month. One of the authors of the current study acted as a facilitator for the project.

The project started with a question sheet on quality problems and their associations (Appendix) that was distributed to all eight accounting department employees. Respondents were asked to rank issues by significance using a scale of 1 to 3 . The questionnaire requested a description of the problem and the respondents' view on the causes of the issue and how it influenced their work.

The answers revealed a range of issues spanning those causing extra work; time-related issues, such as schedule overruns or the slow progress of certain work actions; responsibility and liability issues; knowledge-based problems such as unfamiliarity with software or problems in information flow through the organisation; motivational and coordination issues. Many of the problems listed were not expenditure-generating errors but issues centred on work content.

INSERT FIGURE 2 HERE 
Figure 2 presents the Pareto diagram visualisation made by the researcher to represent the problems reported by the employees via the question sheet. For example, the employees had reported several problems related to rectifying bookkeeping errors, parallel work, and unnecessary work. For analysis purposes, the researcher then grouped these under the 'extra work' class. Similarly, problems grouped under 'time' included issues such as time lost in information seeking, unclear task instructions, or time lost waiting. 'Responsibilities' encapsulated issues around job descriptions. Issues around organisational and individual work development were categorised under 'Development'. Problems related to information flow were grouped under 'information'. Finally, 'motivation' encapsulates issues with staff work motivation, such as feeling underappreciated or under-employed.

It should be noted that the class labels are shortened names and subjectively created categorisations of the complex and partly overlapping problem field, based on which words the employees actually used in their responses on the project question sheet. For example, doing extra work takes time. Although 'time' as such is not a problem, time lost while waiting for a necessary previous element of some service process to be completed can be a problem. There are also several ways of solving these problems, such as improving process flow, machinery, organisation structure, and job descriptions. Further, considering the AR or CAMP method, and change management, the organisational actors are typically better motivated to utilise solutions that they plan themselves (instead of the researcher deciding what is good for them). Allowing the members of the organisation to decide on the corrective actions required also reduces the researcher-based bias and may enhance the validity of the results.

Respondents were asked to evaluate the significance of the quality problems by assigning the most important problem three points, the second most important two points, and all other problems one point. The resulting points were used to assess the size of the problem classes presented in a Pareto diagram (see Figure 2, and Ishikawa, 1985). Accordingly, a large number of issues under a certain class can be read as signifying the organisation has some quite serious issues to address within the particular issues category.

The individual problems reported via the project question sheet were also used to construct the detailed fishbone diagrams (see Appendix). The fishbone diagrams show all individual problems, their causes and impacts, and thus add a cause-and-effect string for every quality problem found in the responses. The fishbone diagrams are generated by taking each individual problem as a centre point (see Ishikawa 1985; Malmi et al. 2004); then arrows depict the direction of the cause-and-effect chain. For example, a mistake in a delivery of the invoice (cause) may result in a problem of invoice coming in two forms, which then results in the invoice being paid twice (impact). Both the Pareto diagram and 
the fishbone diagrams were presented at a workshop to the employees of the department, and they were invited to amend them if necessary. This step was taken to ensure that the research incorporated knowledge from the organisation and to minimise any effect of bias, so increasing the validity of the results.

The first workshop generated some minor specifications to the fishbone diagrams to better reflect the information from the employees, but the categorisation and prioritisation of the various issues remained unchanged. The fishbone diagrams prompted the employees to highlight several of the most important issues that collectively affected their work, one of which was unclear responsibilities. The issue related to the perceived lack of coordination and lack of mutual agreement among employees. Job descriptions were also reported to be inadequate. Another major problem was overlapping work; accounting entries and reports were created outside the department, but since they were not delivered to the department, they had to be created in the department too. The manager highlighted the lack of clarity with regard to the responsibility for development of the department. He commented that the city administration had given him no clear indication of the future and role of the department, which complicated his work on the development of work processes. Finally, another major problem was erratic information flow owing to the absence of systematic processes.

The results from the first workshop were incorporated into subsequent presentations by circling the important topics (see Appendix) and by modifying the problem chains if necessary. This was the starting point for the second workshop, which was intended to devise improvement initiatives. The staff worked in two teams of four to plan improvement initiatives for specific issues. The plans for the initiatives were to label the issue, explain the initiative, set a timeframe for it, nominate the people responsible for its implementation, and forecast expected benefits and cost savings.

The accounting staff at the workshop devised five different improvement initiatives which will be analysed in the next section. These initiatives included 1) the creation of a documentation database, 2) developing software to correct accounting entry mistakes, 3) purchasing software for internal invoicing, 4) mutual coordination of work responsibilities, and 5) work process planning to reduce overlapping work procedures. The last two initiatives needed more planning, coordination, and analysis to implement than the first three which merely involved buying new software, adding certain corrective scripts to existing software, or creating an electronic database. 


\section{Findings}

The case analysis revealed that doing extra work was the most important class of quality issues in the accounting department. The category encompassed several issues including incompatible software products; invoicing process problems; overlapping work processes (both within and outside the department); bookkeeping errors; unclear internal invoicing; and unclear job descriptions. Other sizeable problem categories were time-related and responsibility issues. Time-related concerns centred on software: outdated software created manual work, the software interface was complex, as were file transfers between software products, and there was insufficient software support. Issues reported relating to responsibility included outdated job descriptions, insufficient guidance, and high employee turnover. Table 1 depicts the improvement initiatives, corresponding quality problems identified in the second workshop and the relevant problem categories.

\section{INSERT TABLE 1 HERE}

At the end of the project, the researchers scrutinised the project data. We analysed the problems and initiatives according to their financial impact, the extent to which they were avoidable and whether they occurred within the existing capacity. Furthermore, legislative prevention and appraisal activities such as mandatory risk management and auditing were included in the classification of costs. The results of our analysis are presented below.

Comparing the financial impact of quality problems with the improvement initiatives (Table 1) and the problem classes (Figure 2) shows that the most problematic classes of failure costs (extra work) identified in the case organisation may have little impact on the level of the organisation's financial statement. Both the problems in the extra work category and the improvement initiatives targeting them are largely contained within existing capacity, i.e. resource consumption or financial impact is relatively unaffected regardless of implemented changes. This does not mean that the issues identified could not be addressed, i.e. would be unavoidable in the long run, but because of the cost stickiness peculiar to the public sector (e.g., long term employment contracts leading to fixed costs and firing restrictions), some of the improvements are likely to improve the quality of work instead of delivering actual cost savings. This is one possible explanation for the reported limited impact and disappointing results from public sector improvement initiatives (Lapsley, 2009). However, the high employee turnover rates in the case organisation could mitigate these problems to some extent, allowing some of the salaries to be classed as avoidable expenses. 
The accounting function staff considered the quality problems they identified as having negative effects including inefficiencies, poor quality accounting, and reduced motivation. Some of the quality problems (e.g., those leading to the use of substitutes to cover sick leave) also led to actual cost increases, and illustrate the importance of combining an avoidability analysis with quality data. Our analysis indicates that financial accounting work faces several avoidable quality costs alongside some that are unavoidable (see Table 2).

The predominance of fixed salaries, restrictions on contract termination, and slow capacity adjustments typical of a public sector organisation mean that quality problems can lead to reduced output and efficiency, or low work quality rather than increasing actual expenses. On this issue, Juran (1999) believed that it is not feasible to strive for zero defects as expenses in the appraisal and prevention activities to reach this point would outweigh the benefits. Moreover, the literature on quality has distinguished between service quality and product quality, stating that service quality ultimately always entails some level of error (Mueller et al. 2003). It is suggested that due to human errors and subjectivity also accounting function is likely to contain some unavoidable bookkeeping errors. Further, in some instances, some parallel work may be unavoidable for reasons of risk management and quality control. The case organisation was also working under a specific constraint as its governing municipality had issued a temporary protection order against dismissals as part of merger negotiations with the neighbouring municipality, so reducing the case organisation's capacity management options (Rigid capacity, Table 2).

Corrective actions initiated by the management, like development discussions, agreements on shared values, or clarifying job descriptions, can be thought of as avoidable prevention activities because they are subject to management deciding to cut them and avoid some of the associated costs. However, in Finland municipal legislation dictates some mandatory prevention activities; examples include risk management (mentioned in the Finnish Municipality Act) and quality standards for services. Finally, appraisal costs can be divided into voluntary and mandatory inspection activities, and the case study provided examples of voluntary appraisal activities, including the analysis and coordination of work processes. These constitute a class of avoidable appraisal quality costs. As an example of mandatory inspection, most organisations face a mandatory audit, which constitutes an unavoidable appraisal cost.

\section{INSERT TABLE 2 HERE}

To address our categorisation in Table 2 in terms of cost accounting terminology, it can be noted that avoidable costs tend to include more direct costs, whereas unavoidable costs 
tend to include more indirect costs. Nevertheless, surprisingly large proportion of the quality costs can also be seen as capacity costs and overhead costs in our public sector accounting department. This is because the employment contracts and work duties are such that there are relatively few (or involving low direct cost) products or services that are delivered to customers. Thus, the division of costs is not absolute because many costs typically considered to be direct and avoidable costs in quality costing, such as variable hourly pay of blue collar workers, might be indirect and unavoidable in public sector administrative work, such as a fixed monthly salary. Further, in financial administration, the electronic era is causing a reduction in the traditional direct material costs (e.g. paper and ink).

Analysing the quality improvement in terms of the expenses or savings generated underpins the quality theory (see ASQ, 2014; Crosby, 1979; Feigenbaum, 1991). However, by extending the analysis into the extent to which costs are avoidable, an organisation is able to prioritise its activities in terms of costs it can actually influence within a reasonable period. Some of the quality failures found in the case study do not generate any quantifiable expenses; albeit they undermine the quality of the accounting function. Moreover, the initiatives reported in our case could mostly be implemented in regular working hours and do not add additional expenses. In terms of financial impact, one notable exception is the acquisition of software for internal invoicing. This initiative generates costs through licence fees for the acquired software, even though actual savings may be more oriented towards efficiency. As such, most of the initiatives focused on improving the quality of the accounting function work process. This is not to say that is not an important aim; work satisfaction is a goal in itself, and may, for example, lead to reduced sick leave and eventually to reduced substitute fees. It is also noteworthy that although expenses incurred and savings achieved are not necessarily manifested through quality cost projects, they have considerable potential for workplace improvement and boosting motivation.

While quality theory (ASQ, 2014; Crosby, 1979) sees the reduction in mistakes as savings in quality costs, this view does not necessarily apply fully to public organisations, where activity is tax financed and output level or efficiency does not translate into income. However, since the data received is case specific, in certain projects, actual expenses and savings may be manifested through improvement initiatives more widely.

Our case analysis provides a new classification of different quality costs according to their quality cost class (prevention, appraisal, failure) and the extent to which those costs are avoidable. The quality failures identified in the study are judged to be mainly of the internal avoidable quality failure class, with the exception of faulty external invoices and a certain degree of unavoidable bookkeeping error. Further, the improvement initiatives 
generated fall under either the prevention or the appraisal type of quality costs. In our case, the improvement initiatives are mostly of the prevention type with managerial discretion (avoidable), and it is noteworthy that some of the initiatives generated in the study do not create any real savings or expenses in the short term. We suggest the mandatory external audit is example of an unavoidable appraisal cost that incurs real expense in the case organisation's accounting function, whereas an internal audit is considered an avoidable appraisal activity.

\section{Discussion and conclusions}

The current research investigated the nature of quality costs and the likelihood of their creating financial impacts in the public sector. The issues were illustrated with a quality development case project in the accounting department of a Finnish city administration. The study used an action research (AR) method to analyse the case process (see also Lewin, 1946; Jönsson and Lukka, 2005), and the chosen method for the quality improvement in the organisation was the CAMP method by Malmi et al. (2004). The case revealed several classes of quality problems involving efficiency reductions, reduced output, and motivational issues.

Traditional quality theory holds that investing in prevention and appraisal activities leads to reduced failure costs. However, it is not always clear what constitutes failure in the public sector context, in either short or long term. This is because the ultimate product or service, and their costs and benefits, may be perceived differently according to various stakeholder groups, such as political parties, citizens and professional groups. Further, we found that particularly in the short term, capacity and contractual issues may hinder the objectives of reducing both failure costs and actual costs in the public sector. This leads to some failure costs being sticky, and hence indicates the need for managers to carefully analyse the amount of voluntary investment in prevention and appraisal efforts.

Relating to the discussion on the optimal amount of prevention and appraisal efforts (Juran, 1999), as well as the apparent cost stickiness of some public sector quality costs, we suggest that the amount of optimal prevention and appraisal investments in service oriented public sector organisations is low. We also conclude that cost sticky behaviour (see Balakrishnan et al., 2004, Banker and Byzalov, 2014) of failure costs coupled with inherent subjectivity and human error in service processes (Mueller et al., 2003) mean it is not advisable to target zero defects in such organisations.

It was noted that the public sector context of rigid capacity (e.g., employment contracts) means only some of the quality costs are likely to lead to actual financial expenses (e.g., 
in the form of increased use of substitutes). In the case organisation, high turnover, although detrimental to work fluency, may provide an avenue for capacity management. Detailed analysis of quality cost classes made it possible to categorise the quality costs identified as either unavoidable or avoidable.

Our results suggest that quality costs in the public sector accounting department are not a clear phenomenon; public sector circumstances diminish the financial impact of some quality costs and involve both avoidable and unavoidable costs. The unavoidability of the identified costs and the risk of an unexpected financial impact on some quality activities explains why prior studies have labelled the results of some public sector development projects disappointing (Lapsley, 2009).

In ABC terms (Cooper and Kaplan, 1992), in the public sector there may be less opportunity to downsize excess capacity and the flexibility of decision-making may be lower than in the private sector. Traditional quality theory (e.g. ASQ, 2014) has in some parts overlooked the importance of fixed costs as an obstacle to realising quality savings, particularly in the public sector. In the public sector, excess capacity may not be so easy to turn into additional revenues because many public organisations are not revenue generating, and funding for the production of services is often fixed. Consequently, quality improvements are not so unequivocally good thing as they are in the private sector (Donnelly, 1999). Instead, quality initiatives in the public sector should focus more on the actual financial potential of improvement initiatives prioritising the avoidable quality costs. This means that the quality costs identified in our public sector case organisation are essentially a managerial challenge; these costs should be identified, understood, and effectively managed.

The analysis of the likelihood of actual financial impacts of the quality problems and the extent they are avoidable could be a further refinement of the CAMP tool of Malmi et al., (2004). This kind of detailed cost categorisation and quality cost analysis has the potential to improve classic quality cost analysis, especially in the public sector context. Our analysis offers a way to prioritise process improvement for a public sector organisation by focusing on those quality failures that are avoidable and which generate actual expense. This kind of analysis could optimise actual savings. Moreover, as managerial implications, we expect that capacity management and long term management of resources coupled with the detailed cost analysis suggested in this paper could mitigate the disappointments noted in public sector development projects (Lapsley, 2008, 2009).

The case project identified six major problem classes; extra work, time, responsibilities, development, information, and motivation. Each class encompasses different problems 
related to the chosen topic. Besides bookkeeping errors and software problems, unclear responsibilities were evidently an important problem area in the organisation. This was caused partly by the case manager's unclear communication of job responsibilities to his staff. The manager, in turn, felt that the municipality had not given clear direction on the future or development of the department, resulting in ambiguities. The issue highlights the complex nature of communication problems (see Pärl, 2014); the absence of clear development needs disseminated by the owner (the case municipality) creates ambiguity in managerial practice, which in turn translates into unclear job descriptions and responsibilities, often resulting in increased quality costs. In addition, this problem highlights the issue noted by Kuipers et al., (2014) in that a public sector organisation operates in a different environment from its private counterpart. While efficiency and effectiveness may be seen as more straightforward goals in the private sector (see Kuipers et al., 2014), the public sector organisation may have different, sometimes conflicting goals, thus creating ambiguities in goal setting, cost concepts and quality management. On the other hand, the improvement solutions created in the case illustrate the organisation's potential to alleviate the problem of unclear job responsibilities through improved dialogue and mutual job coordination meetings. Based on a single case material, it is not possible to make strong generalisation regarding wider usefulness of the identified problems or solutions. However, we suggest that the use of different cost concepts (direct/avoidable etc.) deserves more managerial attention in the public sector in order to fully benefit from quality cost projects. Further, similar quality problems as found in our case accounting department are likely to arise in other accounting organisations. These notions serve as propositions for further research.

We argue that quality cost analysis and improvement initiatives, accompanied by cost categorisations, prioritisations, and financial analysis are useful for practitioners and researchers in development projects based in accounting organisations. Although improvement initiatives tend to be case specific and thus cannot be directly transferred to other organisations, the abovementioned arguments regarding the quality analysis may be applicable more widely. However, further research on combining financial and managerial COQ analysis in other contexts would be welcome. 


\section{References}

American Society for Quality. (2014), 'Definition of quality costs', available at: http://asq.org/learn-about-quality/cost-of-quality/overview/overview.html accessed 2.6.2014

Banker, D. and Byzalov, D. (2014), 'Asymmetric cost behaviour', Journal of Management Accounting Research, Vol. 25 No. 2, pp. 43 - 79.

Barber, P., Graves, A., Hall, M., Sheath, D. and Tomkins, C. (2000) 'Quality Failure Costs in Civil Engineering Projects', International Journal of Quality \& Reliability Management, Vol. 17 No. 4/5, pp. 479 - 492.

Balakrishnan, R., Peterson, M. and Soderstrom, N. (2004), 'Does capacity utilization affect the 'stickiness' of costs?', Journal of Accounting, Auditing \& Finance Vol. 19, pp. 283 - 299.

Cooper, R. and Kaplan, R. (1992), 'Activity-Based Systems: Measuring the Costs of Resource Usage', Accounting Horizons, September 1992, pp. 1-13.

Coughlan, P. and Coghlan, D. (2002), 'Action research: Action research for operations management', International Journal of Operations \& Production Management, Vol. 22 No. 2, pp. 220 - 240.

Crosby, P. (1979), 'Quality is free', McGraw Hill, New York, NY.

Donnelly, M. (1999), 'Making the difference: quality strategy in the public sector', Managing Service Quality, Vol. 9 No. 1, pp. 47 - 52.

Dwivedi, R. and Chakraborty, S. (2015), 'An activity-based costing model for an engineering department of an Indian university', International Journal of Accounting and Finance, Vol. 5 No. 1, pp. 62 - 81

Eisenhardt, K. and Graebner, M. (2007), 'Theory building from cases: opportunities and challenges', Academy of Management Journal, Vol. 50 No 1, pp. 25-32.

Emsley, D. (2008), 'Different interpretations of a 'fixed' concept. Examining Juran's cost of quality from an actor-network perspective', Accounting, Auditing \& Accountability Journal, Vol. 21 No. 3, pp. 375 - 397.

English, L. and Guthrie, J. (2003), 'Driving privately financed projects in Australia: what makes them tick?', Accounting, Auditing \& Accountability Journal, Vol. 16 No. 3, pp. 493 - 511.

Erridge, A., Fee, R. and Mcllroy, J. (1998), 'Public sector quality: political project or legitimate goal?', International Journal of Public Sector Management, Vol.11 No. 5, pp. 341 - 353.

Feigenbaum, A.V. (1991), 'Total quality control $3^{\text {rd }}$ revised edition', McGraw Hill Inc.

Freeman, J. (2008), 'The case for quality costing simulation', The TQM Journal, Vol. 20 No. 5 , pp. 476 - 487. 
Foster, S. (1996), 'An examination of the relationship between conformance and quality-related costs', International Journal of Quality \& Reliability Management, Vol. 13 No. 4, pp. 50 - 63.

Harrington, J. H. (1999), 'Performance improvement: a total poor-quality cost system', The TQM Magazine, Vol. 11 No. 4, pp. 221 - 230.

Hewins, M. (1993), 'Accounting for Costs', The TQM Magazine, Vol. 5 No. 4, pp. $39-42$.

Hood, C. (1995), The 'New Public Management' in the 1980s: Variations on a Theme, Accounting, Organizations and Society, Vol. 20 No. 2/3, pp. 93-109.

Horngren, C., Datar, S. and Rajan, M. (2012), 'Cost accounting: A Managerial Emphasis', $14^{\text {th }}$ ed. Global ed. Pearson. Essex. UK.

Hurmelinna-Laukkanen, P. and Heiman, B. (2012), 'Finding the right problems to solve: value creation unpacked', Baltic Journal of Management, Vol. 7 No. 3, pp. $238-250$.

Hyvönen, T., Järvinen, J., Oulasvirta, L. and Pellinen, J. (2012), 'Contracting out municipal accounting: The role of institutional entrepreneurship', Accounting, Auditing and Accountability Journal, Vol. 25 No. 6, pp. 944 - 963.

Ishikawa, K. (1985), 'What is total quality control: the Japanese way', Prentice-Hall International, London, UK.

Juran, J.M. (1999), 'Juran's Quality Handbook', $5^{\text {th }}$ ed. McGraw-Hill

Järvenpää, M. (2007), 'Making business partners: A case study on how management accounting culture was changed', European Accounting Review, Vol. 16 No 1, pp. 99 - 142.

Järvenpää, M., Lähteenmäki, J., Niemelä, M., Pellinen, J. and Voutilainen, V. (2008), 'Hei, me mennään kunnan tilitehtaaseen. Taloushallinnon työn uudelleenorganisoinnin vaikutukset työntekijöiden kokemana', Hallinnon tutkimus (Administrative Studies), Vol. 27 No 2, pp. 52 - 67.

Järvinen, P. (2004), 'Laatukustannukset julkisessa palvelutuotannossa', Julkaisusarja www.aluenet.com, Lahti

Jönsson, S. and Lukka, K. (2005), 'Doing interventionist research in management accounting', Gothenburg Research Institute, report 2005:6.

Kaplan, R.S. and Cooper, R. (1997), 'Cost \& Effect. Using Integrated Cost Systems to Drive Profitability and Performance', Harvard Business School Press, Boston, Ma.

Kearney, T. (2000), 'Why outsourcing is in?', Strategic Finance, January, pp. 34 - 38.

Krishnan, S. (2006), 'Increasing the visibility of hidden failure costs', Measuring Business Excellence, Vol. 10 No 4, pp. 77-101

Kuipers, B., Higgs, M., Kickert, W., Tummers, L., Grandia, J. and van Der Voet, J. (2014), 'The management of change in public organizations: a literature review', Public Administration, Vol. 92 No 1, pp. 1-20. 
Lapsley, I. (1999), 'Accounting and the New Public Management: Instruments of Substantive Efficiency or Rationalizing Modernity?', Financial Accountability \& Management, Vol 15 No 3/4, pp. 201-207.

Lapsley, I. (2008), 'The NPM agenda: back to the future', Financial Accountability \& Management, Vol. 24 No 1, pp. 77 - 96.

Lapsley, I. (2009), 'New public management: the cruellest invention of the human spirit?', Abacus, Vol. 45 No 1, pp. 1 - 21.

Laszlo, G. P. (1997), 'The role of quality cost in TQM', The TQM Magazine, Vol. 9 No. 6, pp. 410 - 413.

Lewin, K. (1946), 'Action research and minority problems', Journal of Social Issues, Vol. 2 No. 4, pp. 34-46.

Malcolm, I. (1999), 'Shared Services: A Manager's Journey', Hoboken, New Jersey: Wiley \& Sons.

Malmi, T., Järvinen, P. and Lillrank, P. (2004), 'A collaborative approach for managing project cost of poor quality', European Accounting Review, Vol. 13 No. 2 pp. 293 - 317.

McKinnon, J. (1988), 'Reliability and validity in field research: some strategies and tactics', Accounting, Auditing and Accountability Journal, Vol 1 No 1, pp. 3454.

Malmi, T. and Granlund, M. (2009), 'In search of management accounting theory', European Accounting Review, Vol. 18 No. 3, pp. 597-620.

Mueller, R., Palmer, A., Mack, R. and McMullan, R. (2003), 'Service in the restaurant industry: An American and Irish comparison of service failures and recovery strategies', International Journal of Hospitality Management, Vol. 22 No. 4, pp. $395-418$

Otley, D. (1980), 'The contingency theory of management accounting: achievement and prognosis', Accounting, Organizations and Society, Vol. 5 No. 4, pp. 413428.

Payne, B. (1992), 'Accounting for improvement', The TQM Magazine, Vol. 4 No. 2

Pollitt, C. (2010) 'Cuts and reforms - public services as we move into a new era', Society and Economy in Central and Eastern Europe, Vol. 32 No. 1, pp. 17-31.

Pärl, Ü. (2014), 'The role of dialogue between executives and ground-level employees mediated by MACS', Baltic Journal of Management, Vol. 9 No 2, pp. 189 212

Redman, T., Mathews, B. and Wilkinson, A. (1995), 'Quality management in services: is the public sector keeping pace?', International Journal of Public Sector Management, Vol. 8 No.7, pp. 21 - 34.

Robison, J. (1997), 'Integrate quality cost concepts into team problem-solving efforts', Quality Progress, March, pp.25 
Roden, S. and Dale, B. (2000), 'Understanding the language of quality costing', The TQM Magazine, Vol. 12 No. 3, pp. 179 - 185.

Schiffauerova, A. and Thomson, V. (2006), 'A review of research on cost of quality models and best practices', International Journal of Quality \& Reliability Management, Vol. 23 No. 6, pp. 647 - 669.

Sedevich-Fons, L. (2011), 'Measuring economic effects of quality management systems', The TQM Journal, Vol. 23 No. 4, pp. 458 - 474.

Sedevich-Fons, L. (2012), 'Integration of quality cost and accounting practices', The TQM Journal, Vol. 24 No. 4, pp. 338 - 351.

Seokjin, K. and Nakhai, B. (2008), 'The dynamics of quality costs in continuous improvement', International Journal of Quality \& Reliability Management. Vol. 25 No. 8, pp. 842-859

Stolber, L. (1991), 'Quality costs - The hidden truth', The TQM Magazine, Vol. 3 No. 1, pp. 7 - 9 .

Tsai, W. (1998) 'Quality cost measurement under activity-based costing', International Journal of Quality \& Reliability Management, Vol. 15 No. 7, pp. 719 - 752 


\section{APPENDIX}

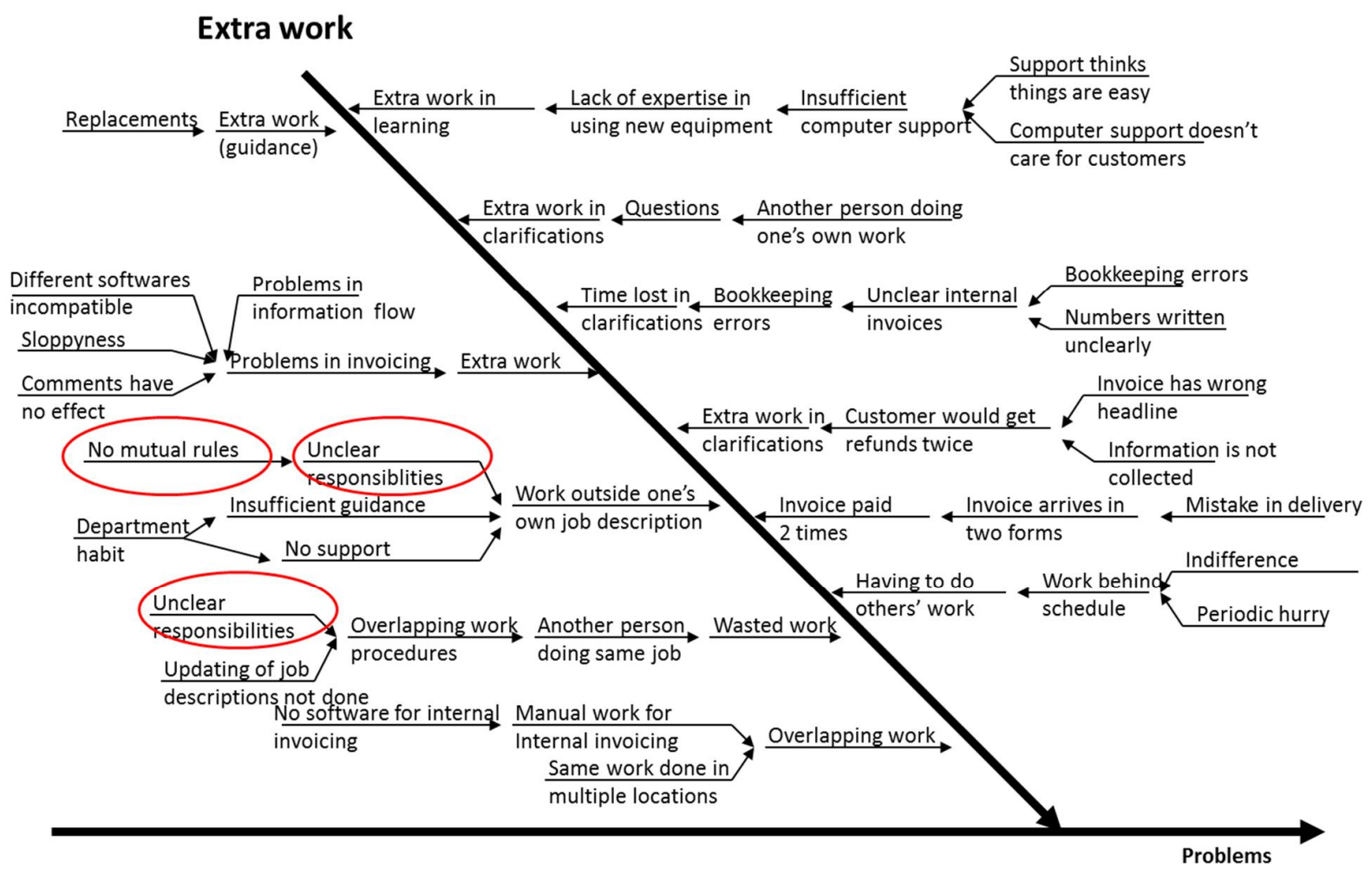

Fishbone diagram of quality problems in the problem class 'Extra work' 


\section{Project question sheet Organisation:}

Provide short descriptions of problems in your work. Describe how the problem affects your work and express your opinion on the cause of that problem. Put the problems in prioritised order by assigning points to them: $3=$ biggest problem, $2=$ second biggest problem $1=$ all others.

\begin{tabular}{|l|l|}
\hline Description of problem: & \\
\hline Effect on work: & \\
\hline Cause of the problem: & \\
\hline
\end{tabular}

\begin{tabular}{|l|l|}
\hline Description of problem: & \multirow{2}{*}{ Importance: } \\
\hline Effect on work: & \\
\hline Cause of the problem: & \\
\hline
\end{tabular}

\begin{tabular}{|l|l|}
\hline Description of problem: & \multirow{2}{*}{ Importance: } \\
\hline Effect on work: & \\
\hline Cause of the problem: & \\
\hline
\end{tabular}

\begin{tabular}{|l|l|}
\hline Description of problem: & \\
\hline Effect on work: & \\
\hline Cause of the problem: & \\
\hline
\end{tabular}

\begin{tabular}{|l|l|}
\hline Description of problem: & \\
\hline Effect on work: & \\
\hline Cause of the problem: & \\
\hline
\end{tabular}




\section{FIGURES}

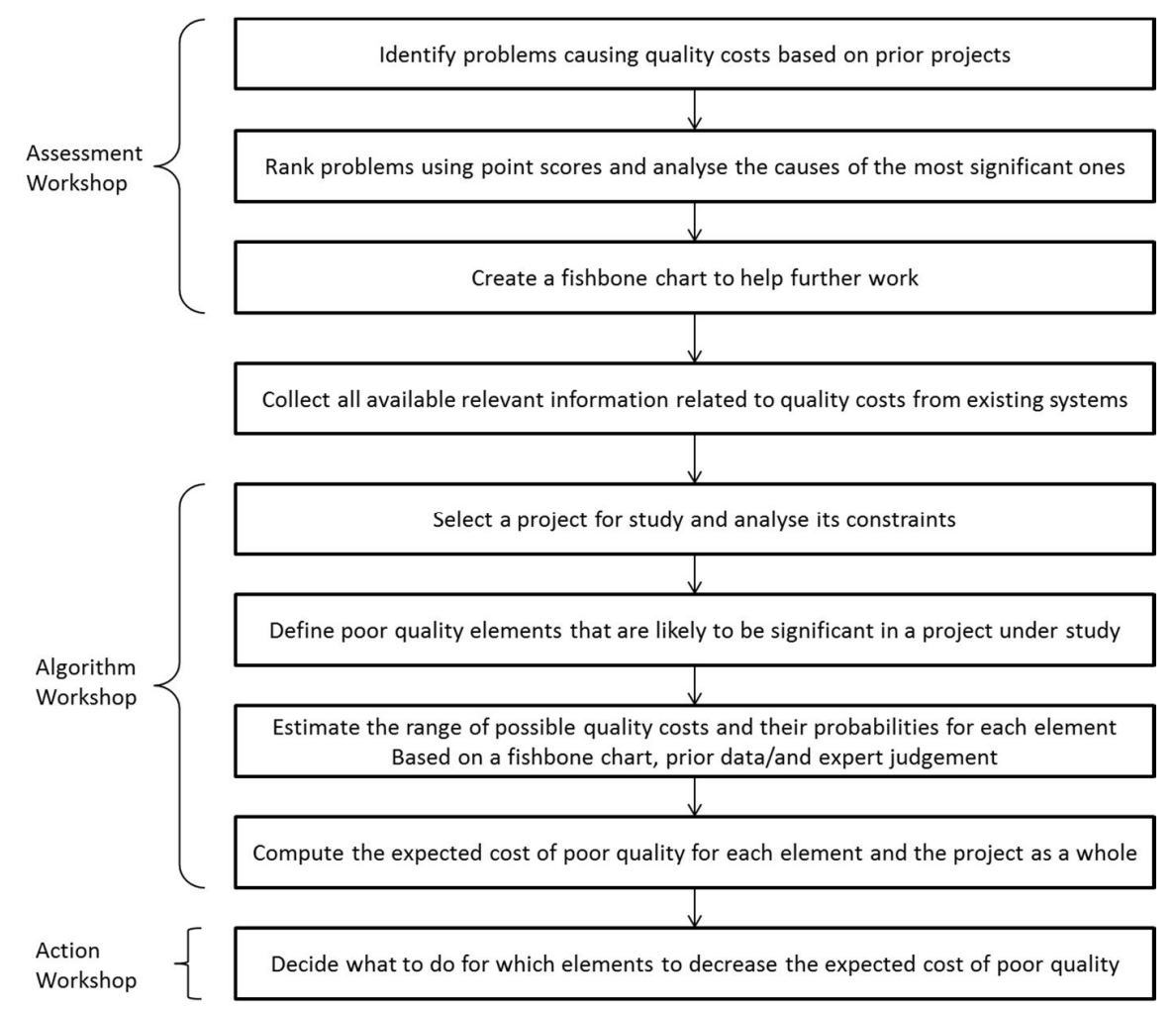

Figure 1 - Process improvement steps (Malmi et al., 2004)

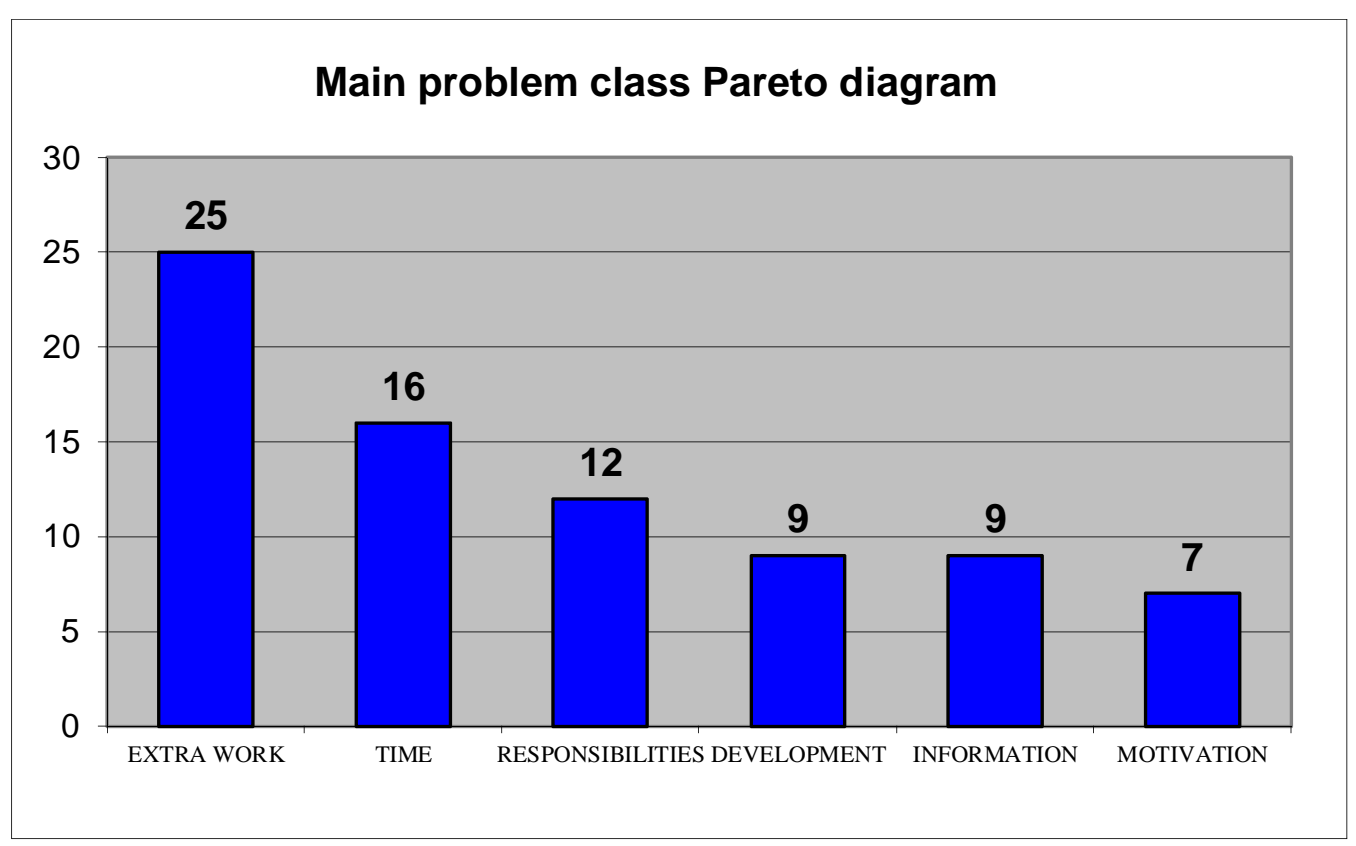

Figure 2: Main problem classes (Pareto diagram) 


\section{TABLES}

\begin{tabular}{|l|l|l|}
\hline Quality problem & Problem class & Improvement initiative \\
\hline $\begin{array}{l}\text { Insufficient coordination of } \\
\text { mutual work processes and } \\
\text { norms }\end{array}$ & Responsibilities & $\begin{array}{l}\text { Mutual coordination of } \\
\text { work processes, creation of } \\
\text { shared values and respect } \\
\text { for others }\end{array}$ \\
\hline $\begin{array}{l}\text { Overlapping work } \\
\text { processes }\end{array}$ & Extra work & $\begin{array}{l}\text { Development discussions, } \\
\text { creation of clear job } \\
\text { descriptions, analysis of } \\
\text { work processes }\end{array}$ \\
\hline $\begin{array}{l}\text { Bookkeeping / accounting } \\
\text { entry mistakes }\end{array}$ & Extra work & $\begin{array}{l}\text { Creation of automatic } \\
\text { corrections to bookkeeping } \\
\text { software }\end{array}$ \\
\hline $\begin{array}{l}\text { No existing electrical } \\
\text { documentation database }\end{array}$ & Time & $\begin{array}{l}\text { Addition of database } \\
\text { feature to bookkeeping } \\
\text { software }\end{array}$ \\
\hline $\begin{array}{l}\text { No software for internal } \\
\text { invoicing }\end{array}$ & Extra work & $\begin{array}{l}\text { Acquisition of software for } \\
\text { internal invoicing }\end{array}$ \\
\hline
\end{tabular}

Table 1: Quality problems in the accounting function, their class, and the improvement initiatives. 
Avoidable

Unavoidable

Failure

Prevention

Appraisal

Traditional failure costs
Waiting for information
Correction of unclear invoices
Searching for papers
Lack of computer support.

(highly likely, low financial impact

if excess capacity exists) financial impact)

failures

\section{Managerial improvement efforts}

Development discussions

Mutual agreements

Automatic correction of entry mistakes

Software for internal invoices (likely to occur, low financial impact if excess capacity exists)

Voluntary (quality) audits

Analysis of work processes

\section{Work related unavoidable failures}

E.g. some bookkeeping issues due to human error (average likelihood, low

\section{Rigid capacity related unavoidable}

Rigid capacity and personnel policies cause unavoidable quality costs, e.g., parallel work (likely to occur, intermediate financial impact)

Coordination of processes (likely to occur, low financial impact if excess capacity exists)

\section{Legislative or municipal changes}

E.g. new risk management practices, municipal quality standard setting for services, municipality-wide acquisition of new software (e.g., SAP)

(likelihood varies over time, high financial impact)

\section{Legislated audits}

Mandatory auditing

City council control (certain, low financial impact if excess capacity exists)

Table 2: Categorisation of quality costs in the public sector accounting context 